Western University

Scholarship@Western

Aboriginal Policy Research Consortium International (APRCi)

4-2009

\title{
Gender and place influences on health risk perspectives in northern Canadian Aboriginal communities
}

Cynthia G. Jardine

Amanda D. Boyd

Christopher M. Furgal

Follow this and additional works at: https://ir.lib.uwo.ca/aprci

Part of the Other Sociology Commons

Citation of this paper:

Jardine, Cynthia G.; Boyd, Amanda D.; and Furgal, Christopher M., "Gender and place influences on health risk perspectives in northern Canadian Aboriginal communities" (2009). Aboriginal Policy Research Consortium International (APRCi). 286.

https://ir.lib.uwo.ca/aprci/286 
This article was downloaded by: [University of Western Ontario]

On: 01 December 2012, At: 07:27

Publisher: Routledge

Informa Ltd Registered in England and Wales Registered Number: 1072954 Registered office: Mortimer House, 37-41 Mortimer Street, London W1T 3J H, UK

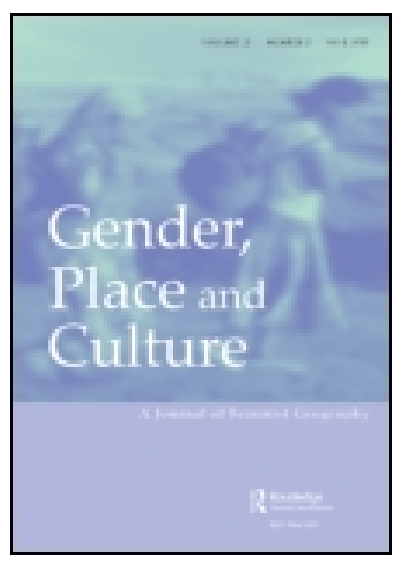

\title{
Gender, Place \& Culture: A J ournal of Feminist Geography
}

Publication details, including instructions for authors and subscription information:

http:// www. tandfonline.com/loi/ cgpc20

\section{Gender and place influences on health risk perspectives in northern Canadian Aboriginal communities}

\author{
Cynthia G. J ardine ${ }^{a}$, Amanda D. Boyd ${ }^{a} \&$ Christopher M. Furgal ${ }^{b}$ \\ ${ }^{a}$ Dept. of Rural Economy, 515 General Services Building, University of Alberta, Edmonton, \\ Alberta, T6G 2H1, Canada \\ ${ }^{\mathrm{b}}$ Depts. of Environmental Resource Studies/Science and Indigenous Studies, 1600 West Bank \\ Dr., Trent University, Peterborough, Ontario, K9J 7B8, Canada \\ Version of record first published: 30 Mar 2009.
}

To cite this article: Cynthia G. Jardine, Amanda D. Boyd \& Christopher M. Furgal (2009): Gender and place influences on health risk perspectives in northern Canadian Aboriginal communities, Gender, Place $\&$ Culture: A J ournal of Feminist Geography, 16:2, 201-223

To link to this article: http:// dx. doi. org/ 10.1080/09663690902795837

PLEASE SCROLL DOWN FOR ARTICLE

Full terms and conditions of use: http://www.tandfonline.com/page/terms-and-conditions

This article may be used for research, teaching, and private study purposes. Any substantial or systematic reproduction, redistribution, reselling, loan, sub-licensing, systematic supply, or distribution in any form to anyone is expressly forbidden.

The publisher does not give any warranty express or implied or make any representation that the contents will be complete or accurate or up to date. The accuracy of any instructions, formulae, and drug doses should be independently verified with primary sources. The publisher shall not be liable for any loss, actions, claims, proceedings, demand, or costs or damages whatsoever or howsoever caused arising directly or indirectly in connection with or arising out of the use of this material. 


\title{
Gender and place influences on health risk perspectives in northern Canadian Aboriginal communities
}

\author{
Cynthia G. Jardine $^{\mathrm{a} *}$, Amanda D. Boyd ${ }^{\mathrm{a}}$ and Christopher M. Furgal ${ }^{\mathrm{b}}$ \\ ${ }^{a}$ Dept. of Rural Economy, 515 General Services Building, University of Alberta, Edmonton, Alberta \\ T6G 2H1, Canada; ${ }^{b}$ Depts. of Environmental Resource Studies/Science and Indigenous Studies, \\ 1600 West Bank Dr., Trent University, Peterborough, Ontario K9J 7B8, Canada
}

\begin{abstract}
Developing a better understanding of the factors underlying health and environmental risk perspectives has been the focus of significant research in recent years. Although many previous studies have shown that perspectives of risk are often associated with gender, sociocultural variables and place, our understanding of the relationship between these factors and risk remains equivocal. A research study was undertaken to develop better insights into the understanding and perspectives of various types of health risks in two sets of northern Canadian Aboriginal communities - the Yellowknives Dene First Nation communities of N'Dilo and Dettah in the Northwest Territories and the Inuit communities of Nain and Hopedale in Nunatsiavut. Gender was found to have a limited overall effect on risk perspectives, consistent with other studies that found no gender differences in communities stressed by multiple and concurrent risks. Nonetheless, subtle gender differences were seen in the qualitative responses, with women focusing more on community impacts and mitigating actions. Threats to 'place-identity' associated with changes in traditional lifestyle and connection to the land were strongly associated with risk perspectives. These results reinforce the need to be cautious in making assumptions about the complex effects of community and personal attributes, such as gender and gender relations, in assessing the factors underlying risk views and concerns. They also suggest the importance of gathering multiple types of data (both quantitative and qualitative) in order to fully assess the effects of both gender and place. Ultimately, understanding risk in a northern context requires recognizing the unique circumstances and identities of northern Aboriginal peoples.
\end{abstract}

Keywords: risk perspectives; risk perception; health; gender; place; Aboriginal; Canada

\section{Introduction}

Developing a better understanding of health and environmental risk perspectives has been the focus of significant academic research in recent years (Slovic 1987; Beck 1992; Slovic et al. 2004). While many different factors have been demonstrated to influence risk views, research has shown that gender often accounts for observed differences in the type and degree of concern, with women generally tending to judge health and environmental risks as being of higher potential hazard than men (Davidson and Freudenberg 1996; Finucane et al. 2000). Previous studies have also shown that knowledge and understanding of risk are strongly associated with culture and different ways of knowing, and that context and situation are critical to understanding how people view and respond to risk (Krimsky and

\footnotetext{
*Corresponding author. Email: cindy.jardine@ualberta.ca
} 
Plough 1988; Satterfield et al. 2004). Similarly, responses to risks have been shown to be related to connections to 'place' and 'place-identity' (Wester-Herber 2004; Masuda and Garvin 2006).

Both gendered attributes (McDowell 1999) and risk perspectives (Kasperson et al. 1988; Johnson and Covello 1987) are acknowledged to be 'socially constructed' in that they are created and developed by society and/or through social and cultural practices. It would seem reasonable to assume that the sociocultural factors which shape gender relations and attributes might also influence the degree and nature of concerns about risks under various circumstances. Correspondingly, these constructed perspectives might be influenced by the environment, society and geographical space within which people reside and with which people interact (Massey 1997, 2005).

There has been considerable research on gender differences in perspectives towards risk and risky activities (for example Finucane et al. 2000; Brody 1984; Stern, Dietz, and Kalof 1993; Roberts 1997; Gutteling and Wiegman 1993). While these researchers do not generally define their understanding of gender, they seem to employ it as both a biological concept (manifested, for example, by attention to women's roles as reproducers and caregivers) and a sociocultural and spatial concept (based on gendered processes of socialization which, for example, characterize women as emotional and men as stalwart). Despite the number of studies that have been conducted, our understanding of the relationship between gender and risk remains equivocal. What has become increasingly obvious is that it is impossible to generalize about gender and risk, as the relative perspectives are highly dependent on both the circumstances and location of the affected parties and the understanding of 'gender' underlying the research. Researchers in this area agree that more study is required to examine the interacting dynamics of gendered relations, sociocultural/environmental variables associated with place, and cumulative risk circumstances on risk understandings and perspectives (Johnson 2002; Freudenberg and Davidson 2007). Limited research has been conducted on understanding risk perspectives within smaller isolated and culturally defined communities, such as the Aboriginal communities in Canada's North ${ }^{1}$ (see, for example, O'Neil et al. 1998; Elias and O'Neil 1995). In particular, few studies done on these populations have specifically investigated if views toward risky or controversial activities are influenced by gendered variables.

The purpose of this article is to determine if there are gendered understandings and perspectives of various risks in two similar, but unique, sets of northern Canadian Aboriginal communities. The results will be examined in the context of particular place-based circumstances and sociocultural environments.

\section{Background \\ Risk and risk perspectives}

Risk is a very complex and multi-faceted concept (Jardine and Hrudey 1997). In the field of risk assessment and risk management, risk has been defined as the answer to three questions: (1) what can go wrong? (hazard); (2) how likely is it to go wrong? (probability); and (3) what happens if it goes wrong? (consequences) (Kaplan and Garrick 1981). This scientific or analytical view of risk is generally based on logic, reason and scientific deliberation. However, risk perception research has shown that risk also has an emotional or affect component, based more on instinctive and intuitive reactions to danger (known as the affect heuristic) (Slovic et al. 2004). Slovic and colleagues (2004) refer to these two ways of comprehending risk as 'risk as analysis' and 'risk as feelings'. They have demonstrated that both are rational and necessary components of risk 
assessment, and that judicious decisions on managing risk require due acknowledgement and proper integration of the two perspectives.

Another important component of risk is the time frame over which the risk will be considered. Risks that have immediate consequences (such as a pandemic influenza) will be viewed differently than risks that have delayed consequences (such as exposure to a contaminant that may result in cancer many years later) (Jardine and Hrudey 1999). Furthermore, experiencing a number of concurrent risks (as opposed to one or two overarching issues or risks that occur successively) will affect the priority and degree of concern for each risk.

Considerable research has been conducted on the various factors which may affect how people view, understand and feel about risks (including but not restricted to: Slovic 1987; Douglas and Wildavsky 1982; Johnson and Covello 1987; Dake 1991; Fishchoff, Lichtenstein, and Slovic 1980; Kasperson et al. 1988; and Sandman 1989). This field of research, commonly referred to as 'risk perception' research, involves investigating the judgments people make when they are asked to characterize and evaluate potentially hazardous substances and activities (Slovic 1987). However, in recent years 'risk perception' has come to be seen by many experts and decision-makers as an obstacle to reasonable and sensible risk decision making on the basis that people irrationally 'perceive' risks at a magnitude not supported through quantitative risk assessment (Sjöberg 1999). As this is contrary to the notion that all components of risk (both analytical and affective) are important (Slovic et al. 2004), many risk scholars now view the term 'risk perception' to be somewhat stigmatized, and instead prefer the use of the terms 'risk perspectives' or 'risk views' to more accurately describe different ways of viewing risk.

\section{Gender and risk}

Many risk research studies over the years have shown that men and women tend to judge health and environmental risks differently, with women generally exhibiting higher levels of concern than men (see, for example, Finucane et al. 2000; Gustafson 1998; Steger and Witt 1989; Stern, Dietz, and Kalof 1993; Flynn, Slovic, and Mertz 1994). Observed differences between men and women in risk response have frequently been attributed to priorities shaped by traditional gender relations, particularly the predominance of economic concerns among men as opposed to the emphasis on children's safety and health among women (Freudenburg and Davidson 2007; Brody 1984; Stern, Dietz, and Kalof 1993; Roberts 1997; Gutteling and Wiedman 1993).

However, there has been little systematic inquiry into explaining gender differences in perceived risk. In an examination of the research literature Davidson and Freudenberg (1996) found that the tendency for women to judge risks as being of higher concern than men is consistent for situations posing very clear risks of contamination, but is more ambiguous for broader issues of environmental concern. The hypothesis that women tend to express greater concern than men about the health and safety implications of technological risks was shown to be consistently supported in the literature. In contrast, the hypothesis that increased knowledge will lead to decreased concern was not well supported, despite repeated examination.

Some studies have examined how observed gender differences may be related to other characteristics, such as race (e.g. Gutteling and Wiegman 1993). Other studies have further suggested that the role of gender or race in perceived risk may be related to sociocultural or sociopolitical factors, such as economics (e.g. Flynn, Slovic, and Mertz 1994). For example, Stern, Dietz, and Kaloff (1993) found that women may hold different beliefs 
than men about the consequences of environmental conditions and/or they may assign different value weights to each type of consequence. However, Savage (1993) found that not only women, but also people with lower levels of schooling and income, and African Americans had more dread of hazards. Finucane et al. (2000) demonstrated that gender and race differences in risk perception in the United States were predominantly due to the $30 \%$ of the white male segment of the population, who tend to judge risks to be extremely low. They termed this the 'white male effect'. In general, the white male group differed from the other groups (females and non-white males) in their sociopolitical attitudes (for example greater confidence in experts, but reduced belief in public-dominated social processes such as government control and egalitarianism). The 'white-male effect' was substantiated in further research by Marshall (2004). Johnson (2002) suggested that observed differences may be based more on white/non-white distinctions than in gender differences. Palmer (2003) extended this further with evidence that both Taiwanese-American males and white males perceived risks as lower than females and other racial groups. To date, the relative effects of gender and race as they intersect with risk have not been adequately explored, whether with respect to sociocultural factors, or with respect to other types of racial differences.

In general, the disparity of research observations would seem to indicate that gendered risk responses may not be generalizable across different situations, contexts and places. Indeed, Freudenburg and Davidson (2007) found that overall differences in risk attitudes between women and men were not always statistically significant, depending on whether risks are currently present or proposed for a specific location, and on the economic circumstances of those affected. Similarly, Greenberg and Schneider (1995) found that observed gender differences in risk perception varied by the degree of environmental distress, with no differences existing in populations stressed by multiple and simultaneous hazards.

\section{Sociocultural and place influences on risk}

Perspectives of risk must be understood within an 'ecological' context which considers the interconnected social, economic and cultural milieus that define different communities and different cultural groups. The ecological paradigm is based on the assumption that people's risk understandings, perspectives and behaviours are determined within a complex and multilevel network of sociocultural community variables (Krimsky and Plough 1988; Stokols 1992). Communities that differ in sociocultural environments will frequently differ in risk responses because these environments serve to frame the judgment processes associated with different types of risks (Vaughan 1995).

There is a growing body of work investigating 'place-based' understandings of risk and their linkages to sociocultural and other variables (Luginaah et al. 2002; Wakefield et al. 2001; Baxter and Eyles 1997D; Ali 1997). People's responses to various risks (especially those associated with external threats) are often strongly associated with 'place-identity' (Wester-Herber 2004). Research has shown that place is central to many aspects of a person's identity, including their feelings of distinctiveness or uniqueness (with respect to culture and traditions), their self-esteem (as reflected by their values and culture), their self-efficacy (or ability to deal with everyday situations) and their feelings of continuity (in relation to established features of their environment) (Twigger-Ross and Uzzell 1996; Gustafson 2001). Externally introduced risks serve to disrupt these aspects of place-identity, and result in heightened anxiety about risks associated with these changes. Masuda and Garvin (2006) showed that place is an important component in the social 
amplification or attenuation of risks in locally contentious environmental debates. The concept of 'social amplification' is premised on the idea that events pertaining to hazards interact with psychological, social, institutional and cultural processes in ways that can heighten or attenuate individual and social perceptions of risk and shape risk behaviour. These risk behaviours may then generate secondary or economic consequences that extend far beyond direct risks to human health and the environment (Kasperson et al. 1988).

\section{Gender, place and risk in northern Canadian Aboriginal communities}

Gendered relations exist in Aboriginal communities in the same way they exist in many other cultures, formed by long-held practices and societal expectations. Traditionally, men have assumed the role of provider, participating in harvesting activities such as hunting, trapping and fishing. Women are responsible for preparing the catch (skinning, butchering and cooking) and for less physically rigorous forms of harvesting, such as berry-picking. Although children are valued by all, women assume the primary role in child rearing. In many northern Aboriginal communities, older women assume a very conservative and uniform style of dress, usually consisting of a skirt and head scarf, which is deemed both appropriate and respectful for their place in society. While some studies have examined gender in Aboriginal cultures and/or northern populations in the context of issues such as culture, nature (Wilson 2005), policy (McGrath and Stevenson 1996), and health (Leipert and Reutter 2005; Healey and Meadows 2007), the linkages between gender and risk have not been generally explored in this cultural group.

The role of place in the north and in Aboriginal communities has, however, received more attention from researchers. Aboriginal peoples feel a strong connection to place, contending that 'the relationship they have with the land shapes the cultural, spiritual, emotional, physical and social lives of individuals and communities' (Wilson 2003, 83). There are strong links between the attributes of place and well-being in these cultures (Richmond et al. 2005). Disruptions to place (environmental, social, political or economic) from external influences beyond the control of the inhabitants result in a sense of being 'out of place', and have been shown to affect the health and healing practices of Aboriginal peoples (Hudson-Rodd 1998; Waldram, Herring, and Young 2006).

Northern Aboriginal communities face a host of common risks. Many are experiencing risks from exposure to environmental contaminants resulting from development activities such as pipeline construction, mining development and military defence (discussed further in the next section). Accompanying these activities has been an increased exposure to (and adoption of) a more 'western' (or maybe more appropriately, 'southern') based lifestyle. This includes a rising consumption of 'store-bought' foods (as opposed to 'traditional' foods, such as wild game, fish and berries), resulting in health issues such as increased obesity, dental caries, cardiovascular disease, anemia, and susceptibility to infection. Of specific concern is the increase in the incidence of Type 2 diabetes in Canadian Aboriginal communities. Rates of diabetes are three to five times higher than those of the general Canadian population, with an alarming increase in diagnosed cases among children. Although Inuit rates of diabetes are not as high as those of other Aboriginal populations, rates are also increasing among this population (Health Canada 2007a).

Health issues associated with addictions are frequently problematic in Aboriginal communities. In the 2004 Baseline Study Among First Nations On-Reserve and Inuit in the North it was reported that $60 \%$ of on-reserve First Nations people between the ages of 18 and 34 currently smoke, and 70\% of Inuit in the north between the ages of 18 and 45 currently smoke. Almost half of the Inuit (46\%) who smoke started smoking at age 14 
or younger, while the majority of on-reserve First Nations people who smoke (52\%) started smoking between the ages of 13 and 16 (Health Canada 2005). Alcohol abuse is also of concern. While Aboriginal peoples have a high rate of abstinence and drink less often than the general population, the proportion of heavy drinkers is higher. The rate of death due to alcohol abuse among Aboriginal peoples is almost twice that of the general population (43.7 per 100,000 versus 23.6 per 100,000) (Sellman et al. 1997). Problems with alcohol and substance abuse exist in the context of the history of colonization and devaluation endured by First Nations and Inuit, which has resulted in a loss of culture (Health Canada 2007b). Addiction problems have been linked to high rates of poverty, family breakdown, unemployment, and disrupted social structure among Aboriginal peoples (Dell and Lyons 2007).

Finally, people in northern Aboriginal communities continue to pursue many traditional activities in a harsh climate and geographical setting which pose inherent risks to their health and well-being (Leipart and Reutter 2005). Winters in these communities are long, extremely cold and characterized by short periods of daylight. Activities such as fishing on the ice in late spring (during break-up), traveling on the land in January (when temperatures are often in the $-40^{\circ} \mathrm{C}$ range), and hunting or trapping far away from the community (where they would be difficult to locate in the event of a mishap) pose significant risks. The geographic isolation experienced by many of these communities also makes travel difficult and frequently results in limited access to health care resources and facilities. However, for many the degree of risk associated with these activities is mitigated by a high degree of familiarity and experience.

\section{The communities}

This research was conducted with two sets of northern Canadian Aboriginal communities the Dene communities of N'Dilo and Dettah in the Northwest Territories, and the Inuit communities of Nain and Hopedale in the newly formed Labrador Inuit Settlement Area (LISA) known as 'Nunatsiavut' ('our beautiful land' in Inuktitut) in northern Labrador (Figure 1).

\section{N'Dilo and Dettah}

N'Dilo and Dettah are part of the Yellowknives Dene First Nation, which falls under the Akaitcho Territory Government. N'Dilo means 'end of the island' and is located at the end of Latham Island, within the municipal bounds of the Northwest Territories capital city of Yellowknife. It was established when the gold mines of Yellowknife were active and has grown to near capacity, with only a few building lots remaining. Dettah means 'the burnt place' and is across the bay of the Great Slave Lake from Yellowknife. It is a 6.5 kilometre drive from Yellowknife by ice road in winter or a 27 kilometre drive on an all-season road. Traditionally, the site was a fish camp for the Dene for hundreds of years before Yellowknife was established. Specific population statistics are only collected for Dettah, which in 2006 had a population of 247 people (Statistics Canada 2007a). Although similar information is not collected for N'Dilo (as it is included as part of Yellowknife for census purposes), the total population is estimated to be about 330 people.

The proximity of both communities to Yellowknife means that members are exposed to a greater urban influence than many other more remote Dene communities in the Northwest Territories. This results in unique sociocultural influences that may affect knowledge, perspectives and behaviours related to health risks and traditional activities. In addition, the people of the Yellowknives Dene First Nation communities are concerned 


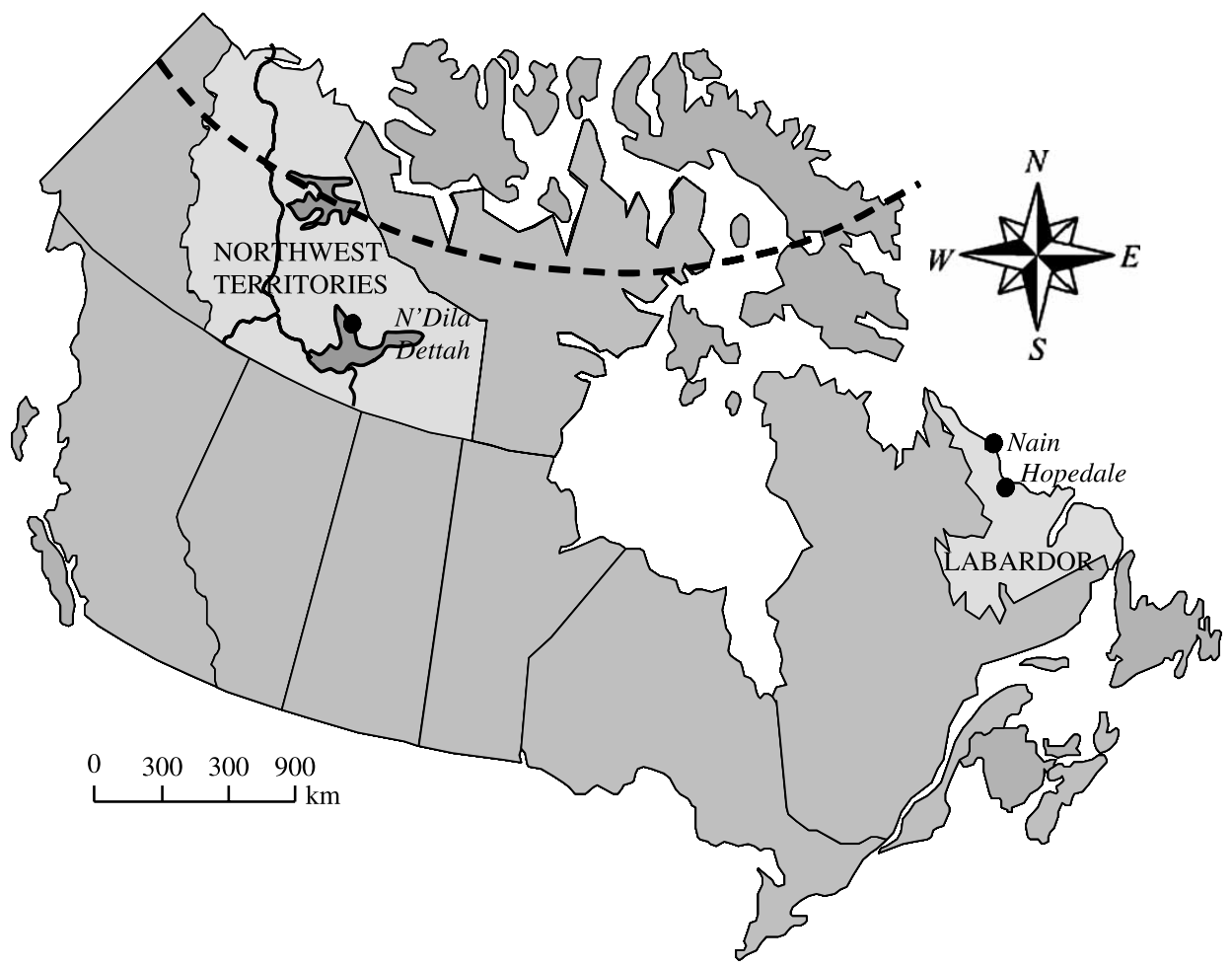

Figure 1. Study locations.

about residual arsenic contamination of their water and land from a former and current gold mine ('Giant Mine' and 'Con Mine') near the City of Yellowknife, and the potential effects of this contamination on human and animal health.

\section{Nain and Hopedale}

In contrast, the Inuit communities of Nain and Hopedale are more isolated 'fly-in fly-out' communities, only accessible by air on a regular basis and in summer by boat. Nain was established as a Moravian mission in 1771 by Jens Haven and other missionaries. In 2006 the population was 1034 people of predominantly Inuit and mixed Inuit-European descent (Statistics Canada 2007b). Hopedale is an original Inuit settlement site, and had a population of 530 people in 2006 (Statistics Canada 2007c). These communities also have a long history of experience with health risks associated with environmental contamination related to the improper disposal of chemicals at decommissioned military radar sites along the coast and concern with regards to the impacts of development of a large scale mineral extraction facility at Voisey's Bay.

\section{Methods}

\section{Data collection}

A research study was undertaken in 2005 to develop better insights into the knowledge, understanding and perspectives of various types of health risks in these two sets of communities. An administered questionnaire was used to collect information on 
demographics, health status, lifestyle, risk perspectives and communication. The questions were based in part on a previous survey conducted by Fletcher et al. (1997) in Kuujjuarapik, Quebec and on similar surveys conducted in Nunatsiavut (Furgal, Powell, and Myers 2005). The questions covered a broad range of community concerns and types of potential risks (for example lifestyle behaviours such as smoking and drinking, physical risks incurred through the pursuit of traditional activities, and risks associated with exposure to environmental contaminants) designed to develop a thorough understanding of the knowledge and views of the multiple types of risks faced in these communities.

The draft questionnaire was translated and back-translated into the local languages (Dogrib in the Northwest Territories and Inuktitut in Nunatsiavut). It was then verified and pre-tested with two or three people in each set of communities to ensure adequate wording, consistent meaning to all respondents and standardized expectations for the type of response (Scheuren 2004; Taylor-Powell 1998; Fowler 1993). Pre-testing also allowed for standardization of interviewing approach and techniques. Feedback from the pre-test was used to modify the interview guides and interviewing procedures. Ethics approval to conduct the research was obtained from the applicable research ethics boards of the two participating universities (University of Alberta and Université Laval).

The questionnaire was administered by trained local community fieldworkers in March and April 2005. The sampling frame was all individuals over the age of 18, which represents about $55 \%$ of the total population for these communities (Statistics Canada 2007a, 2007b, 2007c). Proportional quota sampling was used, with a target of approximately 50 individuals for each of the two sets of communities. This number was chosen on the basis of limitations imposed by the extensive time required for one-on-one interviews and the overall time and budget resources available for the study. In total 107 people participated (50 people in N'Dilo/Dettah and 57 people in Nain/Hopedale). In N'Dilo and Dettah, this sample represents $16 \%$ of the eligible participants in this population, with a confidence interval of $\pm 13 \%$ (at the $95 \%$ confidence level). In Nain and Hopedale, this sample represents $7 \%$ of the eligible participants, with a confidence interval of $\pm 13 \%$ (at the $95 \%$ confidence level). Overall, the sample represents $9 \%$ of the eligible population, with a confidence interval of $\pm 9 \%$ (at the $95 \%$ confidence level). This sample size was considered sufficient to obtain the required rigour through representativeness of the population (Baxter and Eyles 1997).

Initial participant selection was based on a randomized selection of eligible participants from available lists of community members. 'Snowball sampling' - a standard social science technique for developing a research sample where existing study subjects recruit future subjects from among their acquaintances - was then used for subsequent recruitment. As much as possible using these sampling techniques, participants were age and gender stratified according to the population proportions recorded in the last census of each community. However, respondent availability and willingness to participate ultimately dictated the sample composition. The final sample consisted of 29 people in N'Dilo (eight men and 21 women), 21 people in Dettah (nine men and 12 women), 28 people in Nain (14 men and 14 women) and 29 people in Hopedale (17 men and 12 women). Although the gender ratio of participants in N'Dilo/Dettah $(0.52 \mathrm{M} / \mathrm{F})$ was different than that reported for Dettah in the 2006 Census $(0.92 \mathrm{M} / \mathrm{F})$, the gender ratio for Nain/Hopedale (1.19 M/F) more closely approximated the 2006 Census ratio (1.05 M/F). Overall, the sample gender ratio was $0.81 \mathrm{M} / \mathrm{F}$ - just slightly below the combined community ratio of $1.02 \mathrm{M} / \mathrm{F}$. The mean age of participants was between 36 and 45 years 
in both sets of communities, which closely mirrors the age breakdown recorded in the last census (Statistics Canada 2007a, 2007b, 2007c).

The surveys were conducted in the local language when appropriate, and then translated to English for subsequent data entry and analysis. Answers to the open-ended questions were digitally recorded and transcribed verbatim.

\section{Data analysis}

The responses from each questionnaire interview were entered into the computer program SPSS (originally, Statistical Package for the Social Sciences) v.13.5 (later upgraded to v.14.0). Common codes for the open-ended responses were developed and agreed upon by the investigators in both communities. Files were structured so that the data could be analyzed by individual community and for the combined sets of communities.

The data were analyzed using linear regression, as was used in similar previous research on risk perception variables (Savage 1993). Variations among individuals were examined to determine if demographic characteristics, such as gender (one of the independent variables) accounted for the differences in the perceived risks associated with each of the issues presented to the participants (the dependent variable) (Studenmund 2006). This statistical technique was used to better understand the relationship between multiple independent or predictor variables and a dependent or criterion variable. In addition to the regressions for each risk item, a number of risk indices were used, pooling different risk variables to analyze combined risk perspectives. The following semi-log form was used as it provided the 'best fit' over polynomial and linear forms:

$$
\begin{aligned}
Y= & \beta_{0}+\beta_{1} N F L+\beta_{2} \text { Male }+\beta_{3} \ln (\text { Age })+\beta_{4} \text { PostSec }+\beta_{5} \text { Gr } 7 \text { thru } 12+\beta_{6} \text { children } \\
& +\beta_{7} \text { Wage }
\end{aligned}
$$

The first set of models used a linear probability form, testing the overall risk perspectives on social issue problems and concern with children's health. The dependent variables took a dummy variable form, where 'yes' answers were given the value of 1 . For the independent variables, 'NFL' was a dummy variable, taking a value of 1 if the respondent was from the Nunatsiavut region. 'Male' was also a dummy variable, where the value was 1 if the respondent was male. 'Age' was the minimum value of six bands consisting of $18-25,26-35,36-45,46-55,56-65$, and over 65. 'PostSec' and 'Gr7thru12' were dummy variables which indicated the amount of education - the respondent was assigned a value of 1 if he or she had any post-secondary education, or conversely, a value of 1 if they had ceased their formal education somewhere between grade 7 and 12. 'Children' was a dummy variable, taking the value of 1 if the person had children; 'wage' was a dummy variable taking the value of 1 if the person had an occupation earning wages.

The second set of models used multivariate linear equation models to explain $\mathrm{Y}$ as the perceived risk. As mentioned previously, perceived risk was measured on a 5-point Likert scale, with 1 being 'not dangerous at all', 5 being 'very dangerous' and 3 being a 'neutral or don't know' category. The regressions were split into two categories, based on whether the regression had an overall significance or not. Significance at a $10 \%$ level or better was chosen as the dividing point; based on the significance level chosen by Savage (1993).

The discussion in this article is limited to information collected on demographics and the relationships between certain key questions on community assessment of risks and risk 
perspectives. First, the relationship of demographic variables to the responses of two 'yes or no' questions that addressed the overall risk concerns of the community were explored: (1) 'Are there any social issues you think are problems in your community?'; and (2) 'Are you concerned about the future health of the children in your community?' A follow-up open-ended question on the types of social issues or concerns provided additional qualitative insights into these risks. These responses were also coded by category for the purpose of determining the relative magnitude of each issue or concern.

Second, the responses to a multi-part question asking participants to rank a series of risks on a 5-point Likert scale (ranging from $1=$ 'not dangerous at all' to $5=$ 'very dangerous') were examined with respect to demographic relationships. This approach was consistent with previous risk perception research (Slovic et al. 1993, 1995; Krewski et al. 1995a, 1995b). People were asked 'In your opinion, how dangerous are the following things to your health?': (A). Fishing on the ice in late spring; (B). Drinking lots of tea and coffee; (C). Traveling on the land in January; (D). Flying in an airplane; (E). Drinking alcohol while pregnant; (F). Traveling by boat in the fall; $(\mathrm{G})$. Hunting or trapping far away from the community; (H). Inhaling smoke from other people's cigarettes; (I). Store bought food with lots of sugar; (J). Hunting alone in the winter; (K). Smoking cigarettes; (L). Drinking alcohol then driving; (M). Hunting near contaminated areas; $(\mathrm{N})$. Lack of transportation to health care facilities; and $(\mathrm{O})$. Drinking alcohol then driving a boat. The capital letter designator for each risk corresponds to the model number assigned for the purpose of conducting the multivariate linear regressions. When respondents ranked a risk issue at either extreme of the scale (i.e. 'not dangerous at all' or 'very dangerous') they were asked their reasons for choosing this ranking, providing further qualitative insights into their understanding and perspectives of the risk.

\section{Results}

\section{Overall characteristics of respondents}

Slightly more than half of the participants (55\% or 59 people) were female (33 people or $66 \%$ in N'Dilo/Dettah and 26 people or $46 \%$ in Nain/Hopedale). Three-quarters (75\% or 84 people) had children (43 people in $86 \%$ in N'Dilo/Dettah and 42 people or $72 \%$ in Nain/Hopedale). Length of residence in the community was high $-69 \%$ of respondents (74 people) had lived in the community more than 20 years (26 people or $52 \%$ in N'Dilo/Dettah and 48 people or $84 \%$ in Nain/Hopedale), and $39 \%$ (42 people) had lived there all their lives (14 people or $28 \%$ in N'Dilo/Dettah and 29 people or $49 \%$ in Nain/Hopedale). The majority of respondents (76\% or 81 people) rated their health as 'good', 'very good', or 'excellent' (38 people or 76\% in N'Dilo/Dettah and 43 people or 75\% in Nain/Hopedale).

\section{Social problems in the community}

The linear probability model was significant overall for the identification of social issues that are considered problems in the community $(\mathrm{F}=4.553, \mathrm{p}<0.01)$ (Table I). Seventy-three people (68\% of the respondents) believed there were social issues that might be affecting people's health in their community (41 people or $82 \%$ in N'Dilo/Dettah and 32 people or $56 \%$ in Nain/Hopedale). The main issues in N'Dilo and Dettah were alcohol and drug abuse. In Nain and Hopedale, the main issues were alcohol, family issues (such as abuse, neglect, or lack of respect), obesity and poor nutrition, and smoking (including second-hand smoke).

Of the independent variables examined, geographic location had the strongest significance $(\mathrm{p}<0.01)$. Respondents in Nunatsiavut were $25 \%$ less likely than 
Table 1. Analysis of linear probability for the questions on social issues and concerns about the future health of children.

\begin{tabular}{|c|c|c|}
\hline & Social issue problems & Concerned with future health of children \\
\hline \multicolumn{3}{|l|}{ Overall model } \\
\hline F-Test & $3.781 * * *$ & $4.553 * * *$ \\
\hline R Square & 0.211 & 0.244 \\
\hline \multicolumn{3}{|l|}{ Individual coefficients } \\
\hline Constant & -0.100 & 0.244 \\
\hline Nunatsiavut & $-0.246 * * *(-2.984)$ & $-0.258 * * *$ \\
\hline Gender (male) & $0.061 \quad(0.726)$ & $(0.777)$ \\
\hline Post-secondary & $0.337 * *$ & $(0.640)$ \\
\hline Grade 7 through 12 & $0.268 * *$ & $(-0.792)$ \\
\hline Children & $(1.704)$ & $(-1.355)$ \\
\hline Wage & $(0.298)$ & $(1.531)$ \\
\hline $\ln ($ age $)$ & $(1.116)$ & $0.221 * *$ \\
\hline
\end{tabular}

t-scores in parenthesis. $* * * \mathrm{p}<0.01 ; * * \mathrm{p}<0.05 ; * \mathrm{p}<0.10$

respondents in the Northwest Territories to think there are social problems of concern to their community. People with higher levels of education were significantly more likely to express concerns about community social issues than those with less than a Grade 6 education $(\mathrm{p}<0.05)$. However, hypothesis testing using F-values demonstrated that education was not jointly significant to the results. Finally, the likelihood of concern was significantly higher (although at a lower significance level) for respondents who had children $(\mathrm{p}<0.10)$.

Gender was not a significant variable in the acknowledgement of community social problems by participants. However, the open-ended responses on the nature of these concerns, while similar in type of concern, did indicate some qualitative differences between female and male views, particularly for N'Dilo and Dettah. On average, the female respondents in these communities provided longer and more detailed responses, and were more likely to elaborate on the types of effects being experienced by the community and the actions required to deal with the problems:

There's a lot of people that are hurt and hurting - drinking and fighting. They need people to talk to, there are lots of things that happen and people need to be heard, and need to be given tools to help without judging. A lot of people are afraid to get help. Find ways to build good relationships with people and then once they are comfortable, they can start trust-building. If we had a community centre that was run well that would help. When you're busy, and doing healthy positive things, that also keeps you out of trouble, for adults and for kids. (N'Dilo/Dettah female)

In contrast, responses by males were more generally short, consisting of only a few words such as 'drugs and alcohol'. Although only intended to provide explanatatory information on the expressed social concerns, these responses do suggest the significance of assessing how risk perspectives are articulated differently, with reference to the material and socially meaningful practices which constitute gender relations (McDowell 1999), and which for example, constitute women as 'caring' and concerned with issues such as 'building relationships'.

\section{Future health of children}

The responses to the question on the future health of the children in the community also yielded a significant overall model $(\mathrm{F}=3.781, \mathrm{p}<.001)$ (Table 1$)$. In total, $74 \%$ 
of respondents (79 people) were concerned about the future health of children ( $92 \%$ or 46 people in N'Dilo/Dettah and $58 \%$ or 33 people in Nain/Hopedale). The main issues in N'Dilo and Dettah were alcohol, drugs, obesity and poor nutrition, and family issues (such as abuse, neglect, or lack of respect). In Nain and Hopedale, the main issues were smoking (including second-hand smoke) and access to medical care.

As with the identification of problematic community social issues, the most significant independent variable was community location, with respondents in Nunatsiavut being less likely to be concerned with the future health of their children $(\mathrm{p}<0.001)$. Age was also a significant factor $(\mathrm{p}<0.05)$, with older respondents being more likely to have concerns.

While gender was again not a significant variable, the open-ended responses on the nature of the concerns also exhibited some subtle differences between female and male respondents:

Many of our children live in trauma [especially] on the weekends, if there's drinking and fighting. Then they have to come to school, it stops them to learn, because they're dealing with the trauma of their life. Also people drinking while they're pregnant, violence, trauma, FAS [Fetal Alcohol Syndrome], healthy eating. So learning about what's healthy, and about what helps us to grow to be healthy [is important]. (N'Dilo/Dettah female)

Once more, this type of detailed response indicates a gendered perspective on the articulated effects of problems and focus on solutions, rather than the more direct focus on the problem, as exemplified by the male responses (for example, 'kids smoking'). This may indicate that there are gender differences in the way people frame their responses on risk. For example, men may be just as concerned about social problems and the future health of children, but have been conditioned or expected not to show or express this concern as readily as females. Regardless, it is important to stress that, while these observations generally apply to the majority of the qualitative responses, they are not absolute - a few men supplied more detailed responses, and a few women supplied more curt responses.

\section{Risk ranking}

Figure 2 graphically depicts the results of the question asking people to rate the danger of a set of potential risks. The results are provided as an overall risk score, based on weighting each response. The maximum of score of five would indicate that everyone ranked the risk as 'very dangerous'. In both sets of communities, risks associated with drinking and tobacco use were ranked as 'very dangerous' by a very high proportion of respondents, with overall risk scores greater than four.

Table 2 shows the results of the multivariate linear regressions for the eight potential risks (models) that were significantly linked with demographic variables. The other seven risk perspective questions that were tested had overall insignificant values, indicating the variance is probably attributable to factors other than the demographic and place variables used, such as individual characteristics (Savage 1993) or other sociocultural variables.

A second set of correlations and a factor analysis were calculated for the individual risk questions to see if there were any anomalies in the responses. Strong correlations between similar activities indicated relative consistency in the results. For example, smoking cigarettes and inhaling smoke from cigarettes had a strong positive correlation of 0.495. There were also correlations between 'dangerous' lifestyle activities; for example, inhaling smoke from other people's cigarettes and drinking and driving a boat had a strong positive relationship (0.404). 


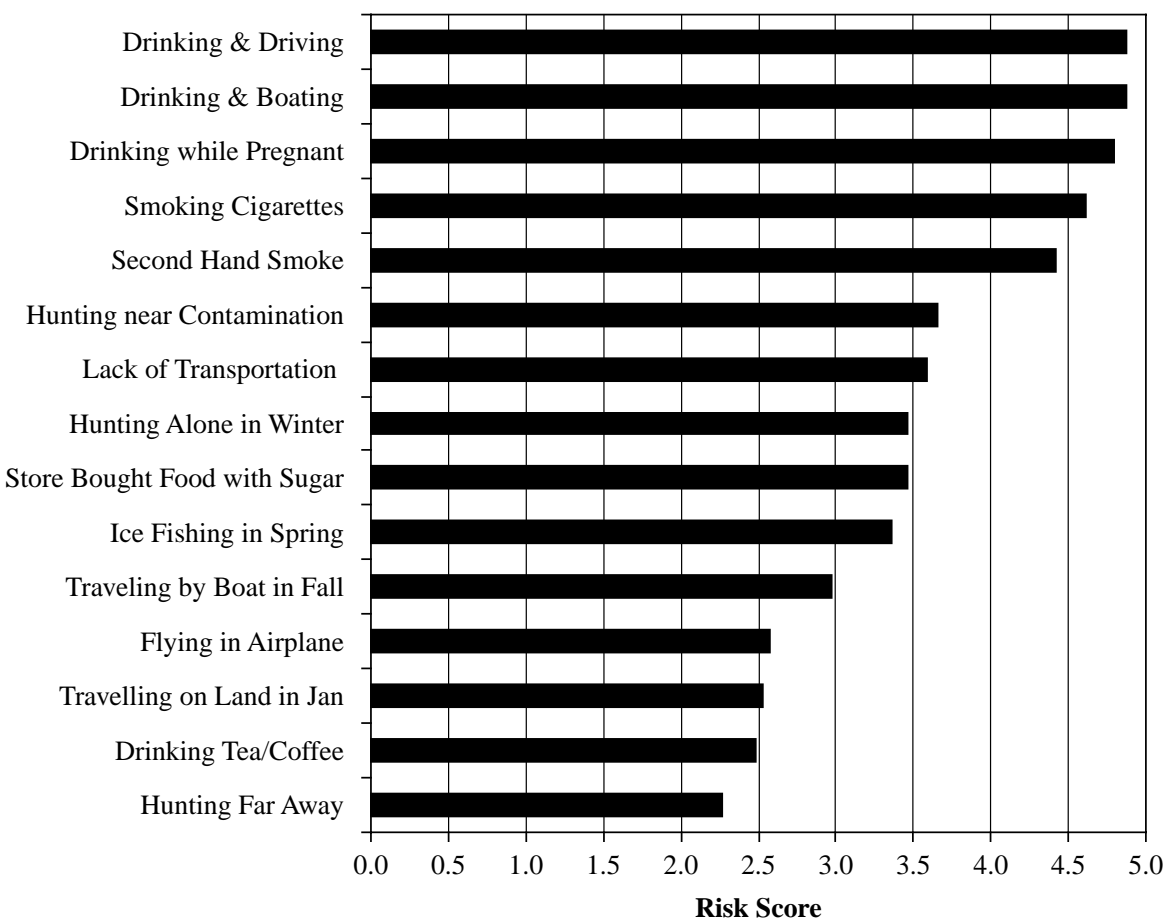

Figure 2. Ranking of the danger associated with various risks by respondents in N'Dilo/Dettah and Nain/Hopedale.

Only two models were significant for gender - 'how dangerous is drinking lots of tea and coffee' (Model B) $(\mathrm{F}=1.86, \mathrm{p}<0.10)$, and 'how dangerous is store bought food with lots of sugar' (Model I) $(\mathrm{F}=4.97, \mathrm{p}<0.01)$. For the latter model, men were less likely to find this activity dangerous by a factor of 0.58 on the five-point ranking scale. The females ranking this risk as very dangerous cited the link to contracting diabetes as their reason. While males also mentioned diabetes when ranking this as very dangerous, several also ranked it as not dangerous at all on the basis that 'you can control how much you eat' and that it is 'just not dangerous'. These perspectives on the acceptability of this risk were primarily voiced by male respondents in Nain and Hopedale. This might indicate that the traditional role of provider somehow conditions males in these communities to think of risk in more personal and individual terms (e.g. decisions about whether to go out on the ice to hunt during freeze-up), whereas females are more conditioned to think about risk in a collective or community-minded sense. However, it should be emphasized that these ideas are only speculative - caution should always be exerted in essentializing on First Nations' culture and gender relations, especially in the absence of specific information on these issues.

Four risks (models) were significant for community or place of residence (Nunatsiavut versus Northwest Territories). In all cases, participants from Nunatsiavut ranked these risks as less dangerous than did participants from the Northwest Territories. The most highly significant difference for the two communities was in their ranking for 'hunting around polluted areas' (Model M) $(\mathrm{F}=7.791 ; \mathrm{p}<0.01)$, which was considered less dangerous by a factor of 1.16 on the five point ranking scale. Significant differences between the two sets of communities were also found for the risk of "drinking alcohol 
Table 2. Analysis of demographic and place variables for significant potential risk models.

\begin{tabular}{|c|c|c|c|c|c|c|c|c|}
\hline & B & $\mathrm{E}$ & $\mathrm{F}$ & $\mathrm{H}$ & I & $\mathrm{K}$ & M & $\mathrm{O}$ \\
\hline & Coffee \& tea & $\begin{array}{c}\text { Alcohol \& } \\
\text { pregnant }\end{array}$ & Boat in fall & Inhaling smoke & Sugary foods & Smoking & $\begin{array}{l}\text { Hunting } \\
\text { polluted }\end{array}$ & $\begin{array}{c}\text { Alcohol \& } \\
\text { boating }\end{array}$ \\
\hline \multicolumn{9}{|l|}{ Overall model } \\
\hline $\begin{array}{l}\text { F-Test } \\
\text { R-Square }\end{array}$ & $\begin{array}{l}1.864 * \\
0.116\end{array}$ & $\begin{array}{l}1.844 * \\
0.115\end{array}$ & $\begin{array}{l}2.119 * * \\
0.130\end{array}$ & $\begin{array}{l}2.155 * * \\
0.132\end{array}$ & $\begin{array}{l}4.967 * * * \\
0.260\end{array}$ & $\begin{array}{l}2.223 * * \\
0.136\end{array}$ & $\begin{array}{l}7.791 * * * \\
0.355\end{array}$ & $\begin{array}{l}2.162 * * \\
0.133\end{array}$ \\
\hline \multicolumn{9}{|l|}{ Individual coefficients } \\
\hline Constant & 3.031 & 6.161 & -0.772 & 4.872 & 0.473 & 4.972 & 4.298 & 5.268 \\
\hline Nunatsiavut & $\begin{array}{c}-0.246 \\
(-1.167)\end{array}$ & $\begin{array}{l}-0.373 * * \\
(-2.847)\end{array}$ & $\begin{array}{c}0.047 \\
(0.185)\end{array}$ & $\begin{array}{c}-0.388 * \\
(-1.896)\end{array}$ & $\begin{array}{c}-0.306 \\
(-1.298)\end{array}$ & $\begin{array}{c}-0.274 * \\
(-1.712)\end{array}$ & $\begin{array}{l}-1.161 * * * \\
(-6.043)\end{array}$ & $\begin{array}{c}-0.110 \\
(-1.483)\end{array}$ \\
\hline $\begin{array}{l}\text { Gender } \\
\text { (male) }\end{array}$ & $\begin{array}{l}-0.527 * \\
(-2.455)\end{array}$ & $\begin{array}{c}0.081 \\
(-0.608)\end{array}$ & $\begin{array}{c}-0.316 \\
(-1.215)\end{array}$ & $\begin{array}{c}-0.314 \\
(-1.508)\end{array}$ & $\begin{array}{l}-0.579 * * * \\
(-2.419)\end{array}$ & $\begin{array}{c}0.127 \\
(0.781)\end{array}$ & $\begin{array}{l}-0.269 \\
(-1.38)\end{array}$ & $\begin{array}{c}-0.118 \\
(-1.569)\end{array}$ \\
\hline Post-secondary & $\begin{array}{c}0.422 \\
(-1.118)\end{array}$ & $\begin{array}{c}-0.052 \\
(-0.222)\end{array}$ & $\begin{array}{c}0.115 \\
(0.252)\end{array}$ & $\begin{array}{c}0.278 \\
(0.76)\end{array}$ & $\begin{array}{l}0.908 * * \\
(2.155)\end{array}$ & $\begin{array}{c}0.458 \\
(1.598)\end{array}$ & $\begin{array}{l}0.687 * * \\
(1.999)\end{array}$ & $\begin{array}{c}0.213 \\
(1.609)\end{array}$ \\
\hline Grade 7 through 12 & $\begin{array}{c}0.217 \\
(-0.641)\end{array}$ & $\begin{array}{c}-0.134 \\
(-0.640)\end{array}$ & $\begin{array}{c}0.014 \\
(0.033)\end{array}$ & $\begin{array}{c}0.559 * \\
(1.703)\end{array}$ & $\begin{array}{l}0.982 * * * \\
(2.603)\end{array}$ & $\begin{array}{l}0.595 * * \\
(2.321)\end{array}$ & $\begin{array}{c}0.515 * \\
(1.675)\end{array}$ & $\begin{array}{c}0.27 * \\
(2.283)\end{array}$ \\
\hline Children & $\begin{array}{r}0.019 \\
(-0.062)\end{array}$ & $\begin{array}{c}0.167 \\
(-0.892)\end{array}$ & $\begin{array}{c}-0.483 \\
(-1.321)\end{array}$ & $\begin{array}{c}0.392 \\
(1.336)\end{array}$ & $\begin{array}{l}0.781 * * \\
(2.316)\end{array}$ & $\begin{array}{c}0.255 \\
(1.111)\end{array}$ & $\begin{array}{c}-0.272 \\
(-0.989)\end{array}$ & $\begin{array}{c}-0.021 \\
(-0.201)\end{array}$ \\
\hline Wage & $\begin{array}{c}0.074 \\
(-0.344)\end{array}$ & $\begin{array}{c}0.080 \\
(-0.595)\end{array}$ & $\begin{array}{l}-0.304 \\
(-1.17)\end{array}$ & $\begin{array}{c}0.177 \\
(0.851)\end{array}$ & $\begin{array}{c}0.095 \\
(0.394)\end{array}$ & $\begin{array}{c}0.178 \\
(1.095)\end{array}$ & $\begin{array}{c}-0.282 \\
(-1.442)\end{array}$ & $\begin{array}{c}-0.021 \\
(-0.279)\end{array}$ \\
\hline $\begin{array}{l}\ln \\
\text { (age) }\end{array}$ & $\begin{array}{l}-0.131 \\
(-0.402)\end{array}$ & $\begin{array}{l}-0.354 * \\
(-1.747)\end{array}$ & $\begin{array}{l}1.217 * * * \\
(3.085)\end{array}$ & $\begin{array}{l}-0.255 \\
(-0.806)\end{array}$ & $\begin{array}{c}0.539 \\
(1.482)\end{array}$ & $\begin{array}{l}-0.292 \\
(-1.182)\end{array}$ & $\begin{array}{l}-0.013 \\
(-0.045)\end{array}$ & $\begin{array}{r}-0.123 \\
(1.08)\end{array}$ \\
\hline
\end{tabular}

t-scores in parenthesis. ***p $<0.01 ; * * \mathrm{p}<0.05 ; * \mathrm{p}<0.10$. 
while pregnant' (Model E) $(\mathrm{F}=1.84, \mathrm{p}<0.05)$ which was considered less dangerous by a factor of 0.37 points on the five point scale. The participants from Nunatsiavut were less likely to believe that inhaling second-hand smoke was dangerous (Model $\mathrm{H}, \mathrm{F}=2.16$, $\mathrm{p}<0.10$ ) (decrease of 0.39 on a scale of 5) than the Northwest Territories participants. The risk of smoking cigarettes (Model $\mathrm{K}, \mathrm{F}=2.22, \mathrm{p}<0.10$ ) was also deemed less dangerous by Nunatsiavut participants than by Northwest Territory participants (decrease of 0.27 on a five point scale).

Education was a significant variable for the perspective of risk associated with 'eating store bought food with lots of sugar' - as education levels increased, the number of respondents ranking this activity as 'very dangerous' also increased significantly $(\mathrm{p}<0.01$ for Grades 7 through 12, and $\mathrm{p}<0.10$ for post-secondary education). Education was similarly significant for the perspective of the degree of danger associated with hunting near contaminated areas $(\mathrm{p}<0.10$ for Grades 7 through 12 , and $\mathrm{p}<0.01$ for post-secondary education). Participants with an education between Grades 7 and 12 felt there was more danger associated with smoking cigarettes. Having more children was a significant variable associated with increased concern about the danger of eating sugar laden foods $(\mathrm{p}<0.10)$. Age was a significant variable for concern about drinking and boating, with older people generally regarding this as a more dangerous activity $(\mathrm{p}<0.01)$. Income levels were not significantly related to any of the measured risk perspective variables.

\section{Risk indices}

The equation for overall perceived risk results was constructed by adding all risk questions from Tables 1 and 2, resulting in a scale with a maximum value of 80 . A score of 80 would be possible if the respondent judged all issues/activities to be of concern or very dangerous. The model was significant at the 5\% level $(\mathrm{F}=2.20)$ (Table 3$)$, with a mean

Table 3. Analysis of demographic and place variables for various risk indices.

\begin{tabular}{lcccc}
\hline & Overall & Smoking & Drinking \& driving & Traditional life \\
\hline Overall model & & & & \\
F-Test & $2.199 * *$ & $2.536 * *$ & $2.552 * *$ & 1.706 \\
R-Square & 0.135 & 0.152 & 0.153 & 0.108 \\
Individual coefficients & & & & \\
Constant & 45.443 & 9.843 & 10.175 & 6.792 \\
Nunatsiavut & -1.688 & $-0.662 * *$ & -0.145 & $1.308 *$ \\
& $(-1.323)$ & $(-2.117)$ & $(-1.415)$ & $(-1.826)$ \\
Male & $-3.491 * * *$ & -0.187 & $-0.188 *$ & $-1.564 * *$ \\
& $(-2.691)$ & $(-0.588)$ & $(-1.810)$ & $(-2.148)$ \\
Post Secondary & 3.402 & 0.736 & $0.446 * * *$ & 0.072 \\
& $(1.490)$ & $(1.315)$ & $(2.442)$ & $(-0.056)$ \\
Grade 7 through 12 & 2.524 & $1.154 * *$ & $0.419 * * *$ & -0.192 \\
& $(1.235)$ & $(2.302)$ & $(2.560)$ & -1.523 \\
Children & -0.414 & 0.646 & 0.024 & $(-1.486)$ \\
& $(-0.227)$ & $(1.443)$ & $(-0.165)$ & 0.150 \\
Wage & -0.106 & 0.356 & -0.108 & $(-0.206)$ \\
& $(-0.810)$ & $(1.117)$ & $(-1.038)$ & $(2.528 * *$ \\
ln & 2.526 & -0.547 & -0.133 & $(-0.845)$ \\
(Age) & $(1.283)$ & $(-1.132)$ & $(288)$ \\
\hline
\end{tabular}

t-scores in parenthesis. ***p $<0.01 ; * * \mathrm{p}<0.05 ; * \mathrm{p}<0.10$. 
of 54.04 and standard deviation of 6.35. Overall, men found the issues/activities to be of less concern or less dangerous than women, with a modest decrease of 3.5 points on a scale of 80 ( $\mathrm{p}<0.01)$. The 'gender' variable was thus highly significant for the combined risk index, even though the magnitude of the effect was not large.

The model examining the perspective of the risks of both inhaling second-hand smoke (an involuntary risk) and smoking (a voluntary risk) showed a significant risk concern for smoking related activities $(\mathrm{F}=2.54 ; \mathrm{p}<0.05)$. The mean of 9.03 was very high, indicating that both smoking related risks were seen by the study participants to be very dangerous. The overall model had a fairly small R-squared value (0.15), meaning that these demographic variables did not adequately explain the observed value. Participants from Nunatsiavut were more likely to have a lower level of concern related to smoking hazards (decrease of 0.66 points on a 10 point scale, $p<0.05$ ). Those who finished Grade 7 to 12 found smoking activities more risky ( 1.15 increase on the scale, $\mathrm{p}<0.05$ ).

Another risk index combined both drinking and driving questions (vehicle or boat) $(\mathrm{F}=2.55 ; \mathrm{p}<0.05)$. The mean risk index was 9.84 and the standard deviation was 0.52 , indicating that most respondents believed that these activities were very risky. The coefficient for 'male' was $0.19(\mathrm{p}<0.10)$, indicating that males are more likely to see drinking and driving activities as less dangerous than females (decrease of 0.19 points on a scale of 10 ). However, this is a small difference and may not have any practical significance. Two other significant coefficients $(\mathrm{p}<0.01)$ were related to education. Participants who had a postsecondary education and those with an education level between Grade 7 and 12 were more likely to believe that these activities were risky (increase of 0.45 and 0.42 points, respectively, out of 10) compared to those with an education level of Grade 6 or less.

The last risk index measured the perspective of risks accompanying traditional activities. These included: 'fishing on the ice in late spring', 'traveling on the land in January', 'traveling by boat in the fall', 'hunting or trapping far away from the community', and 'hunting alone in the winter'. This risk index was combined to produce a scale from 5 to 50 . The minimum value in the study was 5 , and maximum was 23 (mean $=14.59, \mathrm{SD}=3.51)$, indicating that respondents viewed these risks as not very dangerous. The overall model was not significant. This may indicate that people from both sets of communities are more inclined to expect that the risks associated with traditional male pursuits (such as hunting and trapping) can be managed more effectively than those associated with lifestyle related risks (such as smoking, drinking and diet).

\section{Discussion}

Gender and gender relations have a subtle but limited effect on risk perspectives in these two sets of northern Aboriginal communities. These communities currently face many different kinds of existing risks from lifestyle behaviours, development activities and loss of traditional culture and livelihoods. In the face of these multiple and significant risks, concerns are high in terms of both prevalence and degree (especially for social issues and lifestyle behaviours) and generally equally distributed within the population. Although high proportions of both male and female participants expressed concern about social issues affecting their community and the future health of their children, there were not statistically significant differences in responses between females and males. While males were less likely than females to judge risks related to food consumption (drinking lots of tea and coffee, and eating store bought food with lots of sugar) as dangerous, there was no difference between men and women in their assessment of other, more major risks such as those associated with alcohol consumption and smoking. 
These findings are consistent with those of Greenberg and Schneider (1995), who reported that women and men are more likely to be equally concerned about highly visible risks in communities stressed by multiple and concurrent hazards. They are also supported by the work of Freudenberg and Davidson (2007), who noted that gender differences in risk concerns did not manifest in communities currently living in proximity to an existing risk as opposed to communities posed with a potential new risk.

Nonetheless, there are some indications of gendered risk attributes in some of the participant responses. When asked to elaborate on the type and nature of social risks and risks to children, women were more likely to provide more poignant accounts of the effects of the risks and to suggest possible mitigating actions. In terms of overall risk indices, women generally attributed more danger to aggregated risks associated with smoking, drinking and traditional life. This would suggest that gender-based ways of viewing risks play a less overt or implicit role in shaping risk perspectives in stressed environments.

Although not specifically tested in their reported study, Greenberg and Schneider (1995) had noted that their findings might suggest that risk perspectives frequently attributed to other personal and demographic variables such age, education and economic class might similarly change in the presence of multiple hazards. This hypothesis is also validated to some degree in these case studies. The results showed that demographic variables, including gender and factors related to place, are overall significantly related to perspectives of some risky activities in northern Aboriginal Canadian communities. However, only eight of the 16 potential risks presented to study participants were significantly related to demographic variables. Furthermore, there was no consistency in the relative types of risks affected by demographic characteristics - for example, 'drinking alcohol while pregnant' and 'drinking alcohol then driving a boat' were significant models, but 'drinking alcohol then driving' was not. Similarly, one risk associated with traditional activities was significant, but the other four risks related to traditional activities were not. The demographic variables of number of children and age were only occasionally and inconsistently associated with risk perspectives. Income levels were not significantly related to any of the risk perspective dependent variables examined, although education was a significant variable for several risks. Again, this finding demonstrates the need for caution in making assumptions about the factors that may affect risk perspectives.

Even though the hypothesis that socially constructed gender attributes should influence risk perspectives was not proven in this case, the results do suggest that further research into the articulation of risk along gendered lines is warranted, and clearly indicate that geographic place and the sociocultural variables associated with place do seem to affect how individuals in these communities view various types of risks. Geographic place of residence was significant for many risks, with respondents in Nunatsiavut indicating less concern than their counterparts in the Northwest Territories for community social issues, the future health of children and risks associated with drinking and smoking. This might be attributable to several differences in community characteristics. As they are more isolated, the residents of Nain and Hopedale have few other communities against which to reference the extent of their social and lifestyle issues, perhaps resulting in a downplaying of the extent of problems. This might be a comparative risk issue, depending on how residents view a risk relative to the other risks presented. Differences might be related to whether the participants in the two sets of communities used the extremes of the five point scale in the same manner. The nature of concerns was different between the two sets of communities, which might lead to a perceived difference in prevalence and severity. Alternatively, these risks may not be as prevalent in these communities. This is difficult to assess, as the only 
risk that was empirically measured in this study was smoking prevalence, which was actually higher in Nain and Hopedale (where $76 \%$ of respondents reported smoking daily or occasionally, as opposed to $56 \%$ of respondents in N'Dilo and Dettah).

In broader terms of socio-spatial location (i.e. Canada's northern Aboriginal communities) many of the health concerns reported by individuals in all communities are related to aspects of their current social environment. Across all four communities, representatives expressed concern for the health of their community and future of their children, and listed alcohol, drugs, smoking, family issues and obesity as their major concerns. Those activities associated with addictive behaviours (drinking and smoking) were ranked in all communities as being the most dangerous (e.g. drinking alcohol while pregnant). In describing their assessment of these risks, some participants spoke of the 'lack of control' or 'choice' in relation to these addictive behaviours. Participants in this study also expressed concern regarding contamination to their land from anthropogenic sources, although to a lesser extent than lifestyle related risks. Their connection to the land is being threatened by changes to their physical environment, and is being manifested by a decreased participation in traditional activities. Both lifestyle and contamination risks have been externally introduced to these communities and have threatened 'place-identity' concepts of continuity with the land and ability to deal with non-traditional risks (self-efficacy) (Wester-Herber 2004). The results of this study would indicate that these factors have been influential is shaping the risk perspectives expressed by the participants in this study.

\section{Conclusions}

Our understanding of the relationship between gender and risk remains equivocal. The results from this study reinforce the growing recognition that connections between societal and personal attributes, such as gender, and the intertwined material and social practices which shape gender relations, cannot be generalized across different community circumstances and issues; instead the dynamics of place must also be considered. These associations appear to be particularly insignificant for stressed communities experiencing multiple high consequence risks, where all affected individuals display high concern. Risk communicators and risk managers need to be cautious to avoid the fallacy of assuming that risk perspectives can be explained by these attributes.

Nonetheless, gendered perspectives were shown to play a subtle role in risk perspectives in these communities. Although the types and levels of concern were similar amongst all respondents, females were more likely to articulate the full ramifications of the risks on their community and to seek solutions. This finding emphasizes the need to not rely solely on quantitative information when assessing risk perspectives, as qualitative information often provides richer insights into people's knowledge, understanding and concerns, including the nuanced complexities of gender as expressed in sociocultural and socio-spatial ways.

Place clearly matters. Place has a strong connection to how people view various risk issues and the magnitude of their concerns. In this study, threats to a traditional lifestyle and connection to the land ('place-identity') are strongly associated with risk perspectives. This research supports the lessons learned from other studies (such as Furgal, Powell, and Myers 2005 and O'Neil et al. 1998) that understanding risk in a northern context requires an approach that recognizes the unique social, cultural, economic, and political identity of northern Aboriginal peoples. As evidenced by the gender differences revealed when incorporating qualitative measures, it is necessary to go beyond 'standard' methods 
of quantitative data collection to truly assess the complex nature of gender and its influence on risk views and understandings. It is not sufficient for risk researchers to consider gender as a simple 'male' versus 'female' issue. Committing the time and resources necessary to building a relationship and constructive dialogue with people affected by the risk is required to fully understand the nuanced nature of risk responses, and to go behind the notion of gender as a simple one-dimensional biological attribute.

\section{Acknowledgements}

The study was funded by the Health Policy and Research Branch of Health Canada. The case study research in the Northwest Territories communities of N'Dilo and Dettah was conducted by Cindy Jardine, Sandra Malcolm, Louise Beaulieu and Nancy Peel. The case study research in the Nunatsiavut communities of Nain and Hopedale was conducted by Chris Furgal, Susie Bernier, Elizabeth Ford, Mary Denniston, Sarah Karpik, Brenda Jararuse and April Lucy. Robyn Hyde-Lay was the project coordinator. Dr. Sean Cash assisted with the statistical analysis. Drs. Deborah Thien and Neil Hanlon provided invaluable review comments on the manuscript. Studies such as these could not be done without the participation of the members of the communities, and we are grateful to them for sharing their time and views.

\section{Notes on contributors}

Cynthia (Cindy) Jardine is an Assistant Professor in the Department of Rural Economy at the University of Alberta in Edmonton, Alberta, Canada. Her research involves looking at the role of risk communication as a part of a comprehensive risk management strategy, including incorporating pubic perspectives into risk decision making.

Amanda Boyd is currently completing a master's degree in rural sociology at the University of Alberta, focusing on the relationship between media portrayals of risk issues and public understanding of the risks.

Christopher (Chris) Furgal holds a cross-appointment as an Assistant Professor in the Department of Environment and Resource Studies and the Department of Indigenous Studies at Trent University in Ontario, Canada. A particular focus of his work is on the perception and communication of environmental health risk in communities living in rapidly changing natural environments such as coastal and Arctic ecosystems.

\section{Note}

1. In Canada, Aboriginal peoples include the Inuit, Métis and the First Nations (which in the north includes the Dene and Yukon First Nations).

\section{References}

Ali, S. Harris. 1997. Trust, risk, and the public: The case of the Guelph landfill site. Canadian Journal of Sociology 22, no. 4: 481-504.

Baxter, Jamie, and Eyles John. 1997. Evaluating qualitative research in social geography: Establishing 'rigour' in interview analysis. Transactions of the Institute of British Geographers 22, no. 4: 505-25.

Baxter, Jamie, John Eyles, and Susan Elliott. 1999. 'Something happened': The relevance of the risk society for describing the siting process for a Municipal landfill. Geografiska Annaler 81B, no. 2: 91-109.

Beck, Ulrich. 1992. Risk society: Towards a new modernity. Sage: London.

Brody, Charles J. 1984. Differences by sex in support for nuclear power. Social Forces 63, no. 1: $209-28$

Dake, Karl. 1991. Orienting dispositions in the perception of risk: An analysis of contemporary worldviews and cultural Biases. Journal of Cross-Cultural Psychology 22, no. 1: 61-82. 
Davidson, Debra J., and William R. Freudenberg. 1996. Gender and environmental risk concerns: A review and analysis of available research. Environment and Behavior 28, no. 3: 80-9.

Dell, Colleen Anne, and Tara Lyons. 2007. Harm reduction policies and programs for persons of Aboriginal descent. Ottawa, Canada: Canadian Centre on Substance Abuse.

Douglas, Mary, and Aaron Wildavsky. 1982. Risk and culture: An essay on the selection technological and environmental hazards. Berkeley: University of California Press.

Elias, Brenda, and John O'Neil. 1995. A study into the social, cultural, and disciplinary understanding of risk perceptions and risk acceptability of contaminants in the Canadian arctic. Winnipeg: Centre for Aboriginal Health Research.

Finucane, Melissa L., Paul Slovic, C.K. Mertz, James Flynn, and Theresa A. Satterfield. 2000. Gender, race, and perceived risk: The 'white male' effect. Health, Risk, and Society 2, no. 2: 159-73.

Fischhoff, Baruch, Sarah Lichtenstein, and Paul Slovic. 1980. Approaches to acceptable risk: A critical guide. Prep. for the Oak Ridge National Laboratory and U.S. Nuclear Regulatory Commission.

Fletcher, Christopher, Brenda Elias, John O’Neil, and Annalee Yassi. 1997. Health risk perception and hydro-electric development in Kuujjuarapik, Quebec. Northern Health Research Unit, Occupational and Environmental Health Unit: Department of Community Health Sciences, University of Manitoba.

Flynn, James, Paul Slovic, and C.K. Mertz. 1994. Gender, race, and perception of environmental health risks. Risk Analysis 14, no. 6: 1101-8.

Fowler, Floyd J., Jr. 1993. Survey research methods. 2nd ed. Newbury Park, CA: Sage.

Freudenburg, William R., and Debra J. Davidson. 2007. Nuclear families and nuclear risks: The effects of gender, geography, and progeny on attitudes toward a nuclear waste facility. Rural Sociology 72, no. 2: 215-43.

Furgal, C.M., S. Powell, and H. Myers. 2005. Digesting the message about contaminants and health in the Canadian North: Review and recommendations for future research and action. Arctic 58, no. 2: $103-14$.

Greenberg, Michael R., and Dona F. Schneider. 1995. Gender differences in risk perception: Effects differ in stressed vs. non-stressed environments. Risk Analysis 15, no. 4: 503-11.

Gustafson, Per E. 1998. Gender differences in risk perception: Theoretical and methodological perspectives. Risk Analysis 18, no. 6: 805-11.

. 2001. Meanings of place: Everyday experience and theoretical conceptualizations. Journal of Environmental Psychology 21: 5-16.

Gutteling, Jan M., and Oene Wiegman. 1993. Gender-specific reaction to environmental hazards in the Netherlands. Sex Roles 28, nos. 7/8: 433-47.

Healey, Gwen K., and Lynn M. Meadows. 2007. Inuit women's health in Nunavut, Canada: A review of the literature. International Journal of Circumpolar Health 66, no. 3: 199-214.

Health Canada. 2005. Tobacco - First Nation Inuit and health branch. Accessed on September 29, 2007 at http://www.hc-sc.gc.ca/fnih-spni/substan/tobac-tabac/index_e.html.

- 2007a. Diabetes - First Nation Inuit and health branch. Accessed on September 29, 2007 at http://www.hc-sc.gc.ca/fnih-spni/diseases-maladies/diabete/index_e.html.

- 2007b. Fetal alcohol syndromelfetal alcohol effects - First Nation Inuit and health branch. Accessed on September 29, 2007 at http://www.hc-sc.gc.ca/fnih-spni/famil/preg-gros/intro_e. html.

Hudson-Rodd, Nancy. 1998. Nineteenth century Canada: Indigenous place of dis-ease. Health \& Place 4, no. 1: 55-66.

Jardine, Cynthia G., and Steve E. Hrudey. 1997. Mixed messages in risk communication. Risk Analysis 17, no. 4: 489-98.

- 1999. Chapter 17 - What is risk? In Environmental health for all: Risk assessment and risk communication for national environmental health action plans, ed. D. J. Briggs, R. Stern, and T. L. Tinker, 205-11. Dordrecht, The Netherlands: Kluwer Academic Publishers.

Johnson, Brandon B., and Vincent T. Covello, eds. 1987. The social and cultural construction of risk: Essays on risk selection and perception. Boston: Reidel.

Johnson, Brandon B., and Vincent T. Covello, eds. 1987. The social and cultural construction of risk. Dordrecht, Germany: Reidel.

Kaplan, Stanley, and B. John Garrick. 1981. On the quantitative definition of risk. Risk Analysis 1, no. 1: 11-27. 
Kasperson, Roger E., Ortwin Renn, Paul Slovic, Halina S. Brown, Jaque Emel, Robert Goble, Jeanne X. Kasperson, and Samuel Ratick. 1988. The social amplification of risk: A conceptual framework. Risk Analysis 8, no. 2: 177-87.

Krewski, Daniel, Paul Slovic, Sheryl Bartlett, James Flynn, and C.K. Mertz. 1995a. Health risk perception in Canada I: Rating hazards, sources of information and responsibility for health protection. Human and Ecological Risk Assessment 1, no. 2: 117-32.

- 1995b. Health risk perception in Canada II: Worldviews, attitudes and opinions. Human and Ecological Risk Assessment 1, no. 3: 231-48.

Krimsky, Alonzo, and Sheldon Plough. 1988. Environmental hazards: Communicating risks as a social process. Dover, MA: Auburn House.

Leipert, Beverly, and Linda Reutter. 2005. Developing resilience: How women maintain their health in northern geographically isolated settings. Qualitative Health Research 15, no. 1: 49-65.

Luginaah, Isaac N., Martin S. Taylor, Susan J. Elliott, and John D. Eyles. 2002. Community responses and coping strategies in the vicinity of a petroleum refinery in Oakville, Ontario. Health and Place 8, no. 3: 177-90.

Marshall, Brent K. 2004. Gender, race, and the perceived environmental risk: The 'white-male' effect in Cancer Alley, LA. Sociological Spectrum 24: 453-78.

Massey, Doreen. 1997. A global sense of place. In Reading human geography: The poetics and politics of inquiry, ed. T. Barnes and D. Gregory, 315-23. London: Arnold.

. 2005. For space. London: Sage.

Masuda, Jeffrey R., and Theresa Garvin. 2006. Place, culture, and the social amplification of risk. Risk Analysis 26, no. 2: 437-54.

McDowell, Linda. 1999. Gender, identity and place: Understanding feminist geographies. Cambridge: Polity Press.

McGrath, Ann, and Winona Stevenson. 1996. Gender, race, and policy: Aboriginal women and the State in Canada and Australia. Labour/Le Travail 38: 37-53.

O'Neil, John, Brenda Elias, Christopher Fletcher, and Annalee Yassi. 1998. Cultural rationality and environmental health risk perception in Northern Canada. In Issues in the North, Volume 3, ed. J. Oakes and R. Riewe, 13-28. Edmonton: Canadian Circumpolar Institute and Winnipeg: University of Manitoba.

Palmer, Christina G. 2003. Risk perception: Another look at the 'white-male' effect. Health, Risk \& Society 5, no. 1: 71-83.

Richmond, C., S. J. Elliott, R. Matthews, and B. Elliott. 2005. The political ecology of health: Perceptions of environment, economy, health and well-being among 'Namgis First Nation'. Health \& Place 11, no. 4: 349-65.

Roberts, J. Timmons. 1997. Negotiating both sides of the plant gate: Gender, hazardous facility workers and community responses to technological hazards. Current Sociology 45, no. 3: $157-77$.

Sandman, Peter M. 1989. Hazard versus outrage in the public perception of risk. In Effective risk communication: The role and responsibility of government and nongovernment organizations, ed. V.T. Covello, D.B. McCallum, and M.T. Pavlova, 45-9. New York: Plenum Press.

Satterfield, Theresa A., C.K. Mertz, and Paul Slovic. 2004. Discrimination, vulnerability, and justice in the face of risk. Risk Analysis 24, no. 1: 115-29.

Savage, Ian. 1993. Demographic influences on risk perceptions. Risk Analysis 13, no. 4: 413-20.

Scheuren, Fritz. 2004. What is a survey? Accessed on September 29, 2007 at http://www. whatisasurvey.info/.

Sellman, J. Douglas, Terry T. Huriwai, Cliff Fua, Marvin W. Kahn, and Ann M. Roche. 1997. Comments on Landau's: The prospect of a harm reduction approach among indigenous people in Canada. Drug and Alcohol Review 16, no. 1: 87-90.

Sjoberg, Lennart. 1999. Consequences of perceived risk: Demand for mitigation. Journal of Risk Research 2, no. 2: 129-49.

Slovic, Paul. 1987. Perception of risk. Science 236, no. 4799: 280-5.

Slovic, Paul, James Flynn, C.K. Mertz, and Leisha Mullican. 1993. Health-risk perception in Canada. Prep. for the Dept. of National Health and Welfare by Decision Research. Rept. 93-EHD-170.

Slovic, Paul, Torbjörn Malmfors, Daniel Krewski, C.K. Mertz, Nancy Neil, and Sheryl Bartlett. 1995. Intuitive toxicology II. Expert and lay judgments of chemical risks in Canada. Risk Analysis 15, no. 6: 661-76. 
Slovic, Paul, Melissa L. Finucane, Ellen Peters, and Donald G. MacGregor. 2004. Risk as analysis and risk as feelings: Some thoughts about affect, reason, risk and rationality. Risk Analysis 24, no. 2: $1-12$.

Statistics Canada. 2007a. Community profile - Detah. Accessed on September 29, 2007 at http:// www12.statcan.ca/english/census06/dataprofiles/community/Details/Page.cfm?Lang=E\& Geo $1=$ CSD $\&$ Code $1=6106021 \&$ Geo $2=$ PR $\&$ Code $2=61 \&$ Data $=$ Count $\&$ SearchText $=$ detah $\&$ SearchType $=$ Begins $\&$ SearchPR $=61 \& B 1=$ All\&Custom.

. 2007b. Community profile - Nain. Accessed on September 29, 2007 at http://www12. statcan.ca/english/census06/data/profiles/community/Details/Page.cfm?Lang=E\&Geo1= $\mathrm{CSD} \&$ Code $1=1011035 \& \mathrm{Geo} 2=\mathrm{PR} \&$ Code $2=10 \& \mathrm{Data}=$ Count $\&$ SearchText $=$ nain $\&$ Search Type $=$ Begins $\&$ SearchPR $=10 \& \mathrm{~B} 1=$ All $\&$ Custom $=$.

-2007c. Community profile - Hopedale. Accessed on September 29, 2007 at http://www12. statcan.ca/english/census06/data/profiles/community/Details/Page.cfm?Lang $=\mathrm{E} \&$ Geo1= CSD $\&$ Code $1=1011030 \& G e o 2=$ PR $\&$ Code $2=10 \&$ Data $=$ Count $\&$ SearchText $=$ hopedale $\&$ SearchType $=$ Begins $\&$ SearchPR $=10 \& B 1=$ All\&Custom $=$.

Steger, Mary Ann E., and Stephanie L. Witt. 1989. Gender differences in environmental orientations: A comparison of publics and activists in Canada and the U.S. The Western Political Quarterly 42, no. 4: 627-49.

Stern, Paul C., Thomas Dietz, and Linda Kalof. 1993. Value orientations, gender, and environmental concerns. Environment and Behavior 25, no. 3: 322-48.

Stokols, Daniel. 1992. Establishing and maintaining health environments: Towards a social ecology of health promotion. American Psychologist 47: 6-22.

Studenmund, A.H. 2006. Using econometrics: A practical guide. 5th ed. Boston: Addison Wesley Pearson.

Taylor-Powell, Ellen. 1998. Questionnaire design: asking questions with a purpose. Madison WI, University of Wisconsin - Extension. Accessed on September 29, 2007 at http://learningstore. uwex.edu/pdf/G3658-2.PDF.

Twigger-Ross, Claire L., and David L. Uzzell. 1996. Place and identity processes. Journal of Environmental Psychology 16, no. 3: 205-20.

Vaughan, Elaine. 1995. The significance of socioeconomic and ethnic diversity for the risk communication process. Risk Analysis 15, no. 2: 169-80.

Wakefield, Sarah E.L., Susan J. Elliott, Donald C. Cole, and John D. Eyles. 2001. Environmental risk and (re)action: Air quality, health and civic involvement in an urban industrial neighbourhood. Health and Place 7, no. 3: 163-77.

Waldram, James B., Ann D. Herring, and Kue T. Young. 2006. Aboriginal health in Canada: Historical, cultural and epidemiological perspectives. 2nd ed. Toronto: University of Toronto Press.

Wester-Herber, Misse. 2004. Underlying concerns in land-use conflicts - The role of place-identity in risk perception. Environmental Science and Policy 7: 109-16.

Wilson, Kathi. 2005. Ecofeminism and first nations peoples in Canada: Linking culture, gender and nature. Gender, Place and Culture 12, no. 3: 333-55.

Wilson, Kathleen. 2003. Therapeutic landscapes and first nations peoples: An exploration of culture, health and place. Health and Place 9, no. 2: 83-93.

\section{ABSTRACT TRANSLATION}

\section{Las influencias del género y el lugar sobre las perspectivas de riesgo de la salud en las comunidades aborígenes del norte canadiense}

Desarrollar un mejor entendimiento de los factores que subyacen las perspectivas de riesgo de la salud y del riesgo ambiental ha sido el foco de una importante investigación en los años recientes. Aunque muchos estudios previos han mostrado que las perspectivas de riesgo están a menudo asociadas con el género, las variables socioculturales y el lugar, nuestro entendimiento de la relación entre estos factores de riesgo permanece equívoco. Se llevó a cabo un trabajo de investigación para desarrollar una mirada más profunda sobre la interpretación y las perspectivas de varios tipos de riesgos de la salud en dos grupos de comunidades aborígenes del norte canadiense - las comunidades del Pueblo Originario de Yellowknives Dene de N'Dilo y Dettah en Northwest Territories, y las comunidades Inuit de Nain y Hopedale en Nunatsiavut. Se encontró que el género 
tiene un efecto general limitado sobre las perspectivas de riesgo, en concordancia con otros estudios que encontraron ausencia de diferencias de género en las comunidades bajo estrés de múltiples y concurrentes riesgos. A pesar de ello, diferencias sutiles de género fueron vistas en las respuestas cualitativas, con las mujeres enfocándose más en los impactos en la comunidad y las acciones de mitigación. Las amenazas al 'lugar-identidad' asociadas con los cambios en los estilos de vida tradicionales y la conexión a la tierra, fueron fuertemente asociadas con las perspectivas de riesgo. Estos resultados refuerzan la necesidad de ser prudentes a la hora de hacer asunciones sobre los complejos efectos de los atributos de la comunidad y personales, tales como el género y las relaciones de género, al evaluar los factores que subyacen al las visiones y preocupaciones de riesgo. También sugieren la importancia de acumular múltiples tipos de datos (tanto cuantitativos como cualitativos) para poder evaluar a fondo los efectos tanto del género como del lugar. En última instancia, la forma en que se entiende el riesgo en un contexto del norte requiere reconocer las circunstancias e identidades únicas de los pueblos aborígenes del norte.

Palabras clave: perspectivas de riesgo; percepción del riesgo; salud; género; lugar; aborigen; Canadá

\section{性别与地方对于北加拿大原主民族健康风险的观点的影响}

近几年的研究着重于深入了解影响健康以及环境风险的观点的主要因素。虽然许多以往的调查显示有关 风险的观点往往跟性别, 社会和文化因素以及地点有关, 但是我们对这些因素与风险的关系仍然模棱两 可。本研究把焦点放在两个北加拿大的原住民族, 以详细探讨他们对于各种健康风险的了解与观点。这 两个原住民族分别是位于西北地区耶洛奈夫市的恩蒂咯和德他原住民以及位于努纳武特属因纽特民族的 希望谷和内恩。研究指出, 性别对于风险的观点有着有限的影响。这与其它发现遭受多种风险的社群并 没有性别差异的研究是相符合的。然而, 微妙的性别差异能够从定性方法所得出的反应中察觉到。女性 比较注重社区影响以及减轻风险的计划。因传统生活方式以及与土地的联系的变化而造成对' 地方认同 ' 的威胁跟风险的观点是有关联的。这些结果再次强调, 我们不可轻易以例如性别和两性关系等社群与

个人的属性为假设, 来评估影响对于风险的看法与关切的因素。研究结果也揭露了收集多种类型的数据 （包括定量和定性）的重要性, 以便充分地评估性别与地方的影响。毕竟, 了解北部地域的风险必须意 识到北部原住民族的独特情况与个性。

关键词: 风险的观点；风险的认知；健康；性别；地方；原住民；加拿大 